\title{
DEVELOPMENTS AND TRENDS IN THE HISTORY OF ASTROLOGY AND THEIR IMPACT ON THE POPULARISATION OF THE ZODIAC MOTIF IN VISUAL CULTURES OF THE ANCIENT WORLD
}

\begin{abstract}
Although the zodiac as a concept was invented in Babylonia, during the time of the Achaemenid Empire, its earliest visual representations are found in the Hellenistic period. However, the majority of surviving examples of images of the twelve signs date from the Roman Imperial Age. In this paper, we will analyse correlations between important phases in the history of astrology and the appearances of the zodiac motif in different visual forms and periods throughout Antiquity. It is our contention that the increased production of objects and monuments with zodiacal decoration corresponds to periods of increased astrological activity, its presence among the highest echelons of power, their positive attitude towards it, as well as the accessibility of the lower strata of society to the knowledge and practice of astrological theory.
\end{abstract}

\section{KEYWORDS: ASTROLOGY, ASTRAL DIVINATION, ZODIAC, VISUAL CULTURE}

The concept of the zodiac originated in Babylonia. Devised as an imaginary belt encircling the line of the ecliptic, it was used as a coordinate system for determining the position of celestial bodies. It found application in various disciplines, such as astronomy, chronometry, medicine, but its invention had a significant impact on astral divinatory techniques and the formation of astrological theory. Even though both astrology and the zodiac stem from the Achaemenid Empire, the oldest images of the signs date from the Hellenistic period. Whilst only a few examples have survived from this era, most of them have been relegated to a later period by some scholars. ${ }^{1}$ Whichever dating

1 Such is the case with one of the earliest dated images of the zodiac on the "Brindisi disc" ( $4^{\text {th }}$ to $1^{\text {st }}$ century BC, Kerenyi 1976: $386 ; c f$. the end of the $2^{\text {nd }}$ century AD, as proposed by Gury $1986: 475$, $\mathrm{ft}$. 164). The spoliated frieze on the western front of the Little Metropolis Church in Athens with the images of zodiac signs and personifications of Attic months of these monuments we accept, it does not change the fact that the majority of the surviving examples of the zodiac in ancient art belong to the Roman Imperial period. Images of the twelve signs abound in the visual culture of the Roman Empire, where they could be seen all across its vast territories, rendered in various techniques and in different forms. In this paper, we will argue that the popularity of this motif was, to a large extent, influenced by developments and the democratisation of astrological theory and practice. To that end, we will present a brief overview of the history of astrology, as well as an outline of representative ancient monuments containing zodiacal imagery. Thus, we will be able to demonstrate a

has mostly been dated to the I century BC (Webster 1938: 6; Simon 1983: 6-7), but there are scholars who propose a date in the new era (see Boyancé 1942: 195, ft.2.), some even as late as 138/9. AD (Palagia 2008). 
synchronicity between the periods of increased representation of the zodiac in visual media and improvements in astrological calculations, and their availability.

\section{ASTROLOGY AND ASTRAL DIVINATION IN THE ANCIENT WORLD}

From the period of the Babylonian empire, we find the earliest indications of attempts at foretelling the future from the stars. Even though most of them cannot be considered astrology proper, material evidence points to Babylonia as a place of origin of many fundamental elements of astrological learning. In Old Babylon, various celestial phenomena, such as eclipses of the Sun and the Moon, conjunctions of the moon with planets, meteorite strikes, and even certain meteorological events, such as thunder, were considered to be portents from the gods, which is why this form of divination is often called "omen astrology" (Beck 1997: 11). By closely observing and studying these omina, Babylonians started noticing regularities in the movements of the Sun, the Moon and the planets, and soon they were able to develop methods for predicting some of these phenomena. Predictions based on them were recorded and collected, forming a group of some seventy clay tablets known by the name of Enuma Anu Enlil. They were made in the $7^{\text {th }}$ century BC, but it is believed that some of their material dates back to the second millennium BC (Campion 2008: 48).

Following the Persian conquest of Babylon in $539 \mathrm{BC}$, significant achievements were made in the astral sciences. From the tablets made after that time, we can discover that they were able to predict the relative positions of the Sun and the Moon, and the precise dates of conjunctions of planets. However, the greatest advancement was certainly the invention of the zodiac. Even though its development was long and gradual, we can say with certainty that the zodiac of twelve equal $30^{\circ}$ parts, dates back to the $5^{\text {th }}$ century BC. These parts, known as the signs of the zodiac, correlate to a period of time during which the Sun is located in the section of the ecliptic allotted to them. The names of the signs are based on the names of the constellations lying on the path of the Sun, to which they only roughly correspond. The names of these constellations can be found written on tablets from around $1100 \mathrm{BC}$ and among them we can discover "Bull of Heaven", "Great Twins", "Scales", and "Scorpion" (Hunger and Pingree 1999: 50-57).

The invention of the zodiac is one of the major Babylonian contributions to astronomy, allowing for the application of mathematical methods to the astronomical data collected through observation (Powell 2007: 5). It also led to the emergence of horoscopic astrology, a type of astrology which is based on "horoscopes"- diagrams or charts displaying positions of the planets at a certain moment in time. Interpretations of events and circumstances related to that moment are made according to these calculations, as well as predictions of future occurrences. It must be emphasised that the distinction between astronomy and astrology, or rather star-gazing for the purpose of divination, did not exist for Babylonians (Koch-Westenholz 1995: 21). They belonged to the same science dealing with all matters relating to the sky, which included methods and objectives that are today considered to fall into domains of meteorology, chronometry, and agriculture.

The zodiac was not used for astronomical and astrological purposes alone. It was employed for determining the time during the night, as we can find out from Aratus in his astronomical poem Phaenomena (Aratus: 555). It is in this poem, which is known to be based on the lost treatise of Eudoxus of Cnidus dating from around 370, that we find the earliest mention of the zodiac in Greek sources (van der Waerden 1956/7: 216). This means that the Greeks came to be acquainted with the zodiac soon after its invention. They adopted Babylonian names for the signs, translat- 
ing and adapting them, as well as their visual representations. The Greek contribution to astrology was immense, mostly in terms of the application of advances they made in the field of astronomy. They were the first to introduce the spherical concept of the Earth. In the $2^{\text {nd }}$ century BC, Hipparchus discovered the precession of the equinoxes. He also wrote astrological works, which have not survived. Like the Babylonians, the Greeks did not make distinctions between astronomy and astrology, and they used both terms interchangeably (on the uses of these terms throughout history, see Pines 1964: 343-346). Even though names and fragments of works of some of the Greek astrologers are preserved, the Greeks considered as most authoritative the works falsely ascribed to Egyptian authors (most of them were legendary figures such as Nechepso, Petosiris and Hermes Trismegistus). However, there is little proof of any indigenous Egyptian astrology. There are no references to astrological ideas in Egyptian mythology (Dieleman 2003: 140). Ancient Egyptian art is also devoid of astrological motifs. It is only during the time of the Ptolemaic Kingdom that the images of the zodiac started to be represented in temples. The Egyptian contribution to the development of astrology was, in fact, very meagre and was reduced to the introduction of decansa chronometric tool for determining the time of night which, after the zodiac was imported from Babylon, became $10^{\circ}$ divisions of the zodiac.

Romans, likewise, imported astrological learning, whose presence in Rome is referred to by Latin sources already at the end of the $3^{\text {rd }}$ century BC (Tester 1987: 30). The first expulsion of astrologers from the city occurred in 139 BC. Roman intellectual circles were, for a long time, suspicious of astrological theories. Adherence to astrological beliefs was often derided in Latin literature (Cicero: I, 30; Petronius: 39; Juvenal: VI, 552-589). These literary accounts testify to the extent to which astrology had permeated Roman society, but also of the persistence of opposing views towards it. Ambivalent attitudes existed among the highest instances of the Roman government as well. Almost all of the Roman emperors employed court astrologers (Tester 1987: 50). Some of them were very famous and influential, like Thrasyllus, the astrologer to the emperor Tiberius, or Balbilus, astrologer to emperors Claudius, Nero, and Vespasian. From the time of Augustus, the influence and popularity of astrology grew steadily. This influence was recognised by the first emperor and used for his own propaganda. Augustus issued coins with the images of Capricorn, the sign which was of particular importance to him (Barton 1995). In the year 11 $\mathrm{AD}$, when rumours of his impending demise started to circulate, to dismiss those insinuations, he publicly issued his horoscope (Cramer 1954: 83). That same year, Augustus issued an edict which proscribed consultations on certain topics, such as the death of any person, and he also prohibited consultations taking place between the client and astrologer alone (Cassius Dio: 55, 31, 2-3). Such restrictions became common later on and even more strict; in the $1^{\text {st }}$ century alone, astrologers were expelled from Rome and Italy six times (Tester 1987: 51). These banishments were not a sign of distrust towards the validity of the astrologers' creed, on the contrary, they were the result of the desire of emperors to withhold the knowledge of the future from anyone but themselves (Cramer 1954: 236; Mavroudi 2006: 70). Nothing is more illustrative of the nature of the imperial attitude towards astrology than the example of Septimius Severus, whom Cassius Dio claims had the ceiling of every reception hall in his palace painted with his nativity, so that everyone could see the splendid future fate had in stall for him (Cassius Dio: $77,11,1)$. The ascendant was, however, displayed in a different position in every hall, to confuse those who wanted to predict the time of his death. Certain emperors were even believed to be practicing astrologers themselves, and some sources claim that of the emperors Tiberius and Hadrian (Cassius Dio: 55, 10a; Scriptores Historia Augusta: I, 16, 7). 
The practice of astrology flourished throughout the Empire, as we can deduce from the great number of extant horoscopes. A bulk of horoscopes on papyri have survived from the $2^{\text {nd }}$ century CE. Most of them display unique features and methods, perhaps indicating that at the time there was no single standardised form of astrology or a book that enjoyed the status of an authoritative astrological handbook (Tester 1987: 46). That was about to change when, in the second half of the $2^{\text {nd }}$ century, the famous Ptolemy wrote his Tetrabiblos, which was to become one of the most canonical books on astrology for centuries to come. Ptolemy, a famous geographer and astronomer from Alexandria, was also considered to be the foremost authority on astrology for almost a millennium and a half. For those who apply modern scientific criteria to pre-modern periods that might seem peculiar, however, for Ptolemy himself, and for many generations after him, astronomy and astrology were complementary disciplines. Although we have other influential $2^{\text {nd }}$ century astrologers, like Vettius Valens, no one contributed to the development of astrology as Ptolemy, who systematised the existing body of knowledge and endeavoured to provide a rational and scientific explanation for the functioning of its principles. He successfully demythologised astrology, avoiding mythological references and mystical notions. He went on to explain how planets exert their influence on the events on Earth, as if discussing any other physical law of nature. Even though there were other Greek thinkers who expressed a naturalistic understanding of astrology, Ptolemy was the first to do so in a systematic and comprehensive manner, in accordance with current philosophical and scientific ideas. Also, by separating astrology from the realm of Greco-Roman gods and hermetic mystical speculations, he made it acceptable for adherents of different religions, particularly Christianity and Islam, in whose hands the future of astrology lay.

Religious cults in Antiquity also played an important part in the promotion of astrological ideas. Even though we do not have any scriptural accounts attributed to worshipers of Mithra, astrology must have been a significant element in their belief system, as can be inferred from the abundance of zodiacal and astral imagery in their devotional art. The same can be assumed for many other cults in the Roman Empire. Other material evidence also points to the practice of astrology within some religious groups. In the village of Grand, in the French province of Lorraine, pieces of ivory tablets carved with the images of the zodiac and decans were excavated from the bottom of a well in the late 1960s. The village of Grand housed a sanctuary dedicated to Apollo Grannus, where pilgrims sought healing and assistance from the god. Ivory fragments found in the well just outside the city walls were a part of an astrologer's board that were most probably destroyed on purpose around 170 AD (Evans 2004: 5). Similar ivory fragments bearing figures identified as zodiac signs were found in the Nakovana cave on the Pelješac peninsula in the year 2000 (Forenbaher and Jones 2011). Since the latest of the finds from this cave sanctuary are dated to the $1^{\text {st }}$ century BC and the results of the systematic field survey suggest this area was uninhabited during the entire Roman period, due to ravaging during the Roman military campaigns in Illyria that started in $35 \mathrm{BC}$, that same year can be taken as a terminus ante quem for the deposition of the engraved ivory plaques in the cave sanctuary. Direct radiocarbon dating also supports such an early date, which makes the Nakovana zodiac the oldest known astrologer's board (ibid.: 433). Both the Grand and Nakovana tablets are thought to have been produced in Egypt, as is the Tabula Bianchini, a marble fragment containing segments of concentric zodiac rings which was found on the Aventine Hill in 1705, and is now preserved in the Louvre Museum (Evans 2004: 7). Perhaps the most famous Egyptian zodiac is the one represented on the ceiling of the chapel dedicated to Osiris in the Hathor temple in Dendera, now also in the Louvre. The zodiac could also be seen in the tem- 
ples of Edfu and Esna (Plunket 1903: 231; Clagett 1995: 126). The presence of astrology in Egyptian temples is conveyed by Clement of Alexandria, who claimed that astrologers participated in the ceremonials and that the priests were well versed in Hermetic literature (Clement: VI, 4, 35-36). Material support for Clement's accounts is provided by astrological ostraca excavated from the temple in the village of Narmouthis, today's Medinet Madi, and an ostracon found near the sanctuary in Tebtunis, all of which are dated to the $2^{\text {nd }}$ century CE (Evans 2004: 26). Astrological ideas were also present in the cult of Sarapis; a great number of gems engraved with the images of Sarapis and astral symbols might point to the practice of astral magic among the followers of this cult (ibid.: 20, 22). The receptivity of various cults to astrology reveals how this divinatory technique exhibited a twofold appeal: it could provide "scientific" rules and explanations for a correlation between everyday events and the stars, but it could also possess a mystical-religious character of revelation which was transmitted through Hermetic literature and other pseudo-epigraphic texts.

\section{VISUAL REPRESENTATIONS OF THE ZODIAC IN THE ANCIENT WORLD}

As we can see in the previous section, images of the zodiac dated to the years before our era are rare, and among the few securely dated examples are the fragments of an astrologer's board from the Nakovana cave. Whilst the dating of most other examples is a matter of controversy, none of them are dated to the time before the Hellenistic period (see $\mathrm{ft} .1$ ). Although representations of individual signs can be found in Assyro-Babylonian visual culture, there are no indications that the zodiac with the twelve signs was depicted on their monuments and objects, nor that it was even conceived as an individual motif. Some of the animals belonging to the circle of the zodiac, such as lions, bulls, scorpions, and goats, were represented on kudurrus, but their zodiacal meaning or any astral connotations cannot be confirmed (Iwaniszewski 2003).

The twelve signs depicted together in their standardised and recognisable form are found on monuments and objects from the first half of the $1^{\text {st }}$ century. Images of the signs were used in the decoration of private spaces and objects, such as the "Zodiac vase" made in the municipium of Calagurris in modern Spain (Barrata 2014) and wall painting of Domus Uboni and Casa di Sirico in Pompeii (on frescoes from both houses, signs are depicted on the shield of Achilles in the scenes of Thetis in the forge of Vulcan, Hardie 1985: 18). In a much more public setting, the signs were displayed on the ceiling of the southern adytum of the temple of Bel in the city of Palmyra in Syria. The temple, which was consecrated in $32 \mathrm{AD}$, was almost completely destroyed by members of the Islamic State in 2015, and along with it, the monumental zodiac which surrounded the flat dome filled with relief fields showing the busts of the personifications of the seven planets with the Bel-Jupiter as the central one.

Gods and zodiac signs are often paired together on the monuments of Roman art. They can be seen on the base of a three-sided marble candelabrum from the Augustan age (the candelabrum, which was probably made in Rome, was once part of the Borghese collection, and is now held in the Louvre museum; Long 1987, 16, 38-9, 296-7). On every side, a deity is shown mounted on an anthropomorphised sign of the zodiac. A similar iconographic formula of gods riding the zodiac signs is repeated on a $3^{\text {rd }}$ century mosaic from Hellín in the province of Albacette, now on display at the Museo Arqueologico Nacional in Madrid (idem 1989: 592-3). One of most famous monuments containing images of the twelve gods and twelve signs is the so-called "Altar of Gabii". It was excavated at the forum of the ancient town of Gabii, east of Rome, in the spring of 1792 and was later purchased as a part of the Borghese collection by 


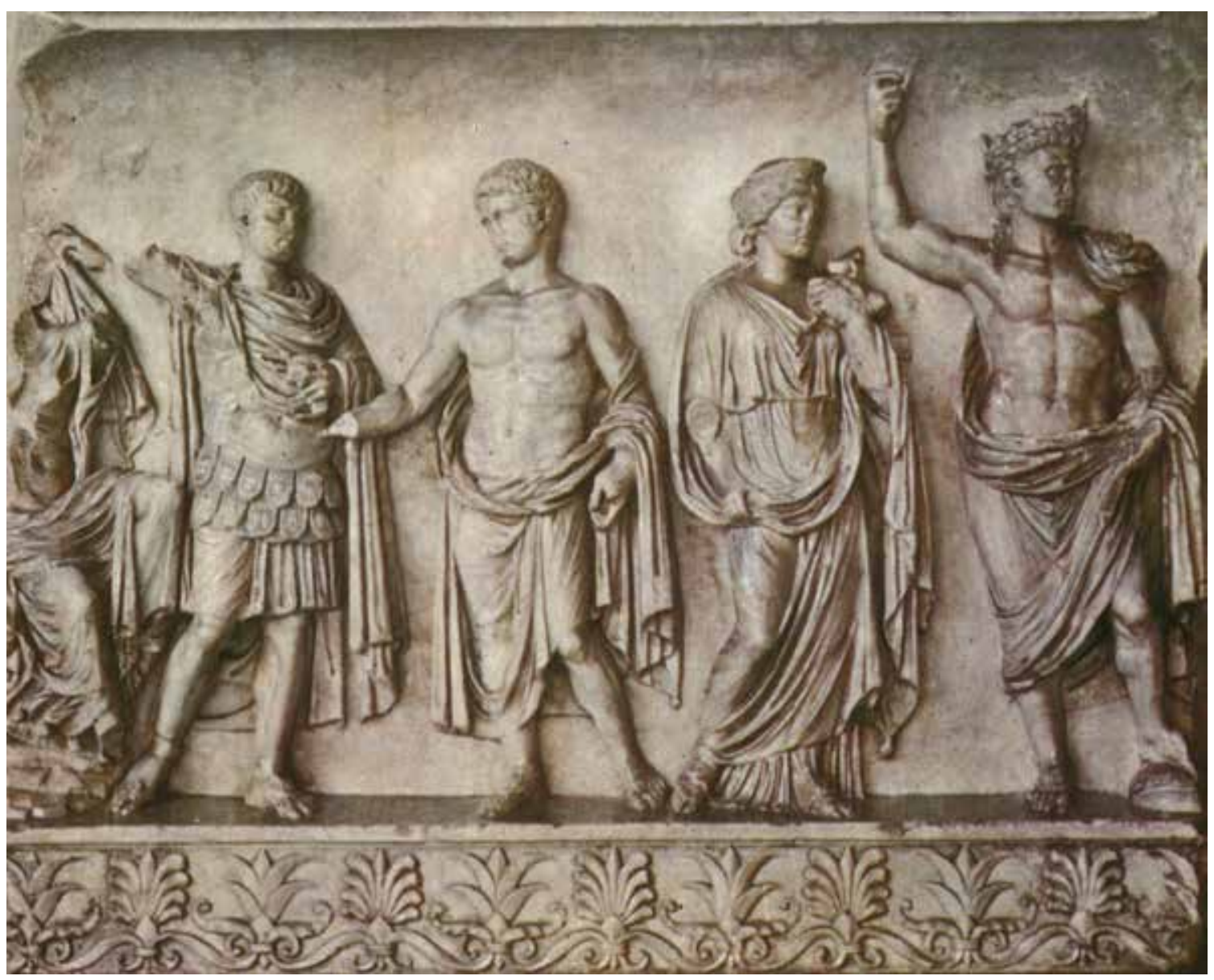

Fig 1. "Ravenna Relief”, Museo Nazionale di Ravenna (after Keler 1970: 93)

Napoleon and taken to the Louvre Museum (Long 1987: 14, 294). Charlotte Long assumes it was made in the Hadrianic period; she doubts that it had a cultic purpose or, as was also presumed, that it was used as a sundial, since horizontal sundials were rare in Antiquity (loc. cit).

The zodiac signs can be seen on time-measuring and time-keeping devices, but more often in their written form. The names of the signs are inscribed on the bronze plates of the so-called Antikythera Mechanism. This object, which was found by a Greek sponge-diver in a shipwreck off the coast of this small island, has proven to be a very sophisticated instrument which could determine the movements of certain planets, as well lunar and solar eclipses. It is dated to the $5^{\text {th }}$ century $\mathrm{BC}$ by some scholars and to the $2^{\text {nd }}$ century BC by others (see Hannah 2009: 29-31). The names of some of the signs were also recognised in bronze Greek letters uncovered on Campus Martius by Edmund Buchner in 1976. They were a part of a Horologium-Solarium which Augustus had set up in 9 BC (for the history of the excavation and different theories regarding this complex, see Jacobus 2005: 376-9).

Images of the signs can be observed on the cippus Colotianus, a $1^{\text {st }}$ century marble column representing a kind of rustic calendar, recording for every month of the year the number of days in the month, the position of the Sun, the tutelary deity, festivals and agricultural activities. All this information is organised in columns, and on top of each column is placed a figure of the zodiac sign ruling over that month (it is held in the National Archaeological Museum in Naples. Long 1987, 267; of similar design and content was the now lost menologium rusticum Vallense. Idem 1989: 


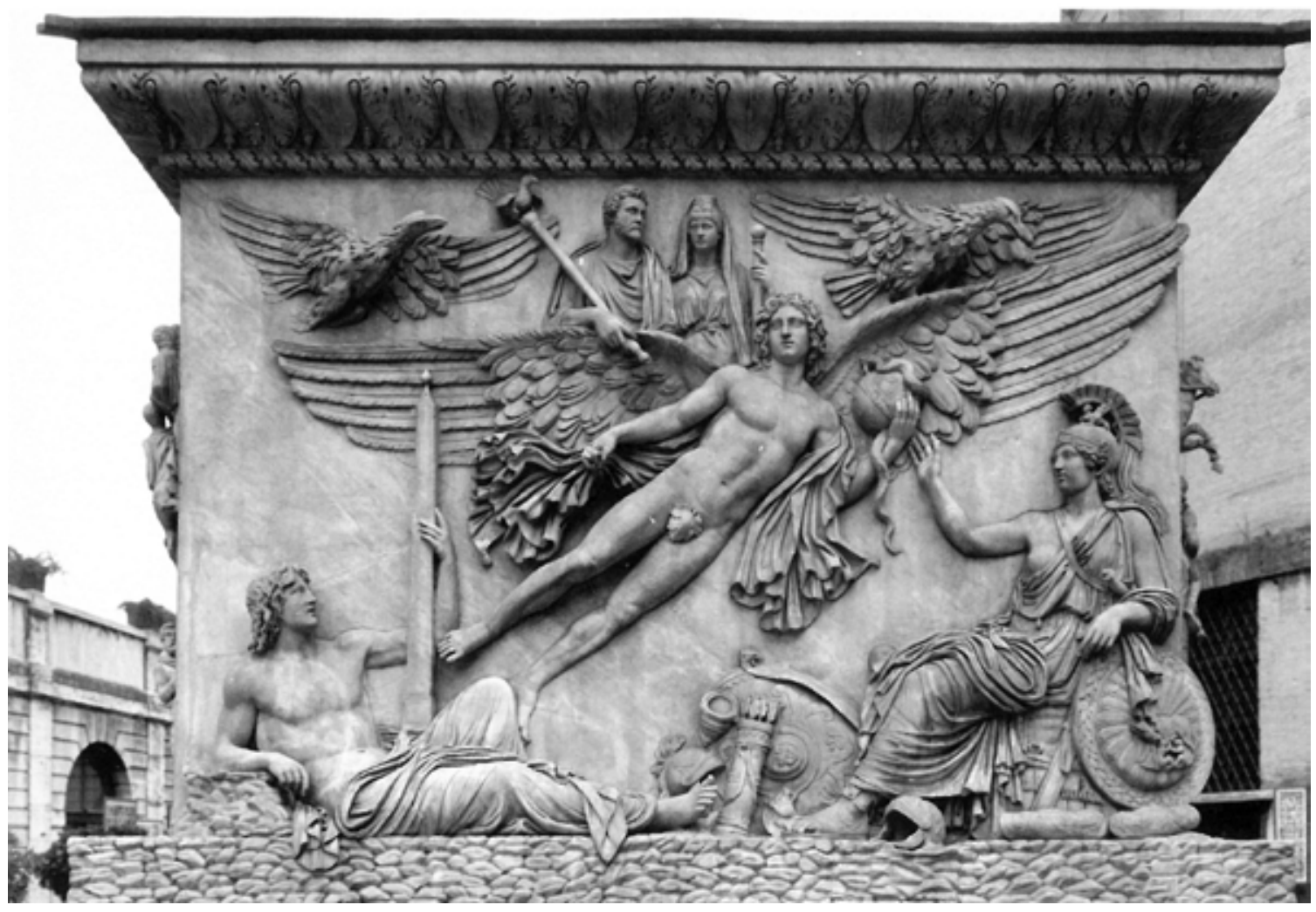

Fig. 2a. Column of Antoninus Pius, apotheosis relief, Rome

(after Davies 2004, fig. 33)

589). Zodiac figures could also be seen on parapegma, a type of calendar in which data was recorded by means of pegs inserted into holes chiselled next to the days of the week, months, phases of the Moon, etc. A $4^{\text {th }}$ century parapegma was excavated in 1812 in a house near the Baths of Trajan, later converted into an oratory dedicated to Santa Felicita. Since it was inscribed in graffito on the wall of the shrine, which was destroyed in 1822 , it is known to us through plaster casts and other reproductions (Lehoux 2007: 16, ft. 33, 34). The zodiac signs filled the segments of the circle in the centre, while busts of seven deities presiding over seven days were represented above.

Zodiacal imagery was present on some of the earliest star maps in Antiquity. Among the most famous is certainly the "Farnese Atlas" in the National Archaeological Museum in Naples, which is a $2^{\text {nd }}$ century Roman copy made after a Hellenistic model whose dating is still debated (Schaefer 2005; Duke 2006). As on other uranographic images, the figures of the zodiac are shown together with the other constellations. In the $2^{\text {nd }}$ century $\mathrm{AD}$ another type of globe appeared, whose only figural ornamentation were the images of the signs. They were usually a part of a larger work of art, yet there are some that are preserved on their own, such as a large marble globe from Sala dei Busti in the Vatican or a smaller example kept in the Landesmuseum Württemberg in Stuttgart (Bodnár 2007: 100). A similar zodiac globe can be seen on the famous "Ravenna relief" (Museo Nazionale, Ravenna, fig. 1). Once belonging to a larger monument, possibly an altar, this relief shows various members of the Julio-Claudian dynasty (Torelli 1992: 78). While the identity of some of the figures has been disputed, the figure on the far right is undoubtedly Divus Augustus (Pollini 2012: 218). The Ravenna relief is sometimes called the Apotheosis of Augustus, which some scholars believed to be its subject matter (Keler 1970: 92). In fact, images of the zodiac are often present on scenes of Apotheosis. A zodiac globe can also be seen on another famous Apoth- 


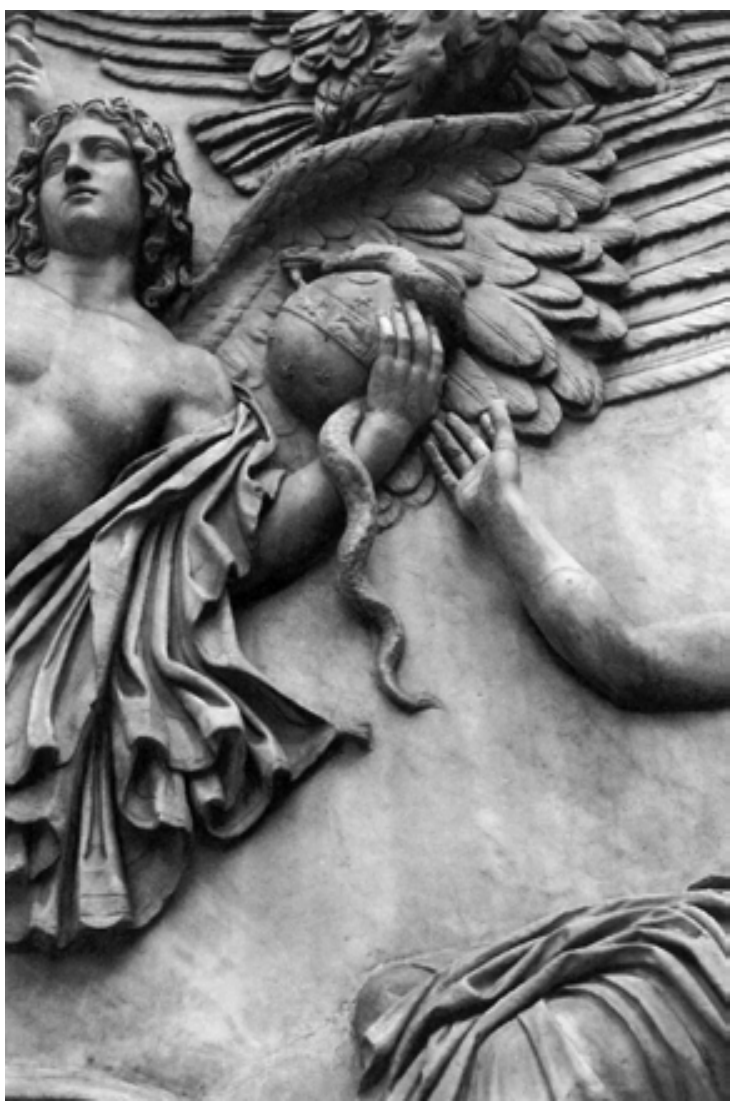

Fig. 2b. Column of Antoninus Pius, apotheosis relief, Rome, detail (after Davies 2004, fig. 62)

eosis relief, the one on the base of the column of Antoninus Pius (fig. 2. a, b). The globe is held by a winged nude male, who carries the emperor and his wife Faustina heavenward. Five stars, a crescent moon and a zodiacal band are carved on the globe. The signs that are visible are those of Pisces, Aries, and Taurus. Their choice was not arbitrary. As Penelope Davies had pointed out, it was under the sign of Pisces that Antoninus Pius died, and his heirs, Marcus Aurelius and Lucius Verus, who commissioned this column, acceded to the throne. Also, these signs designate spring, thus symbolising a spring like regeneration that the rule of Antoninus' adoptive sons was to bring about (Davies 2004: 99). A zodiac globe can also be seen on the portrait of the last emperor of the Antonine dynasty. It is placed at the base of the bust of Commodus represented as Hercules, now in the Palazzo dei Conservatori (fig. 3). This globe is also decorated with band showing three zodiac

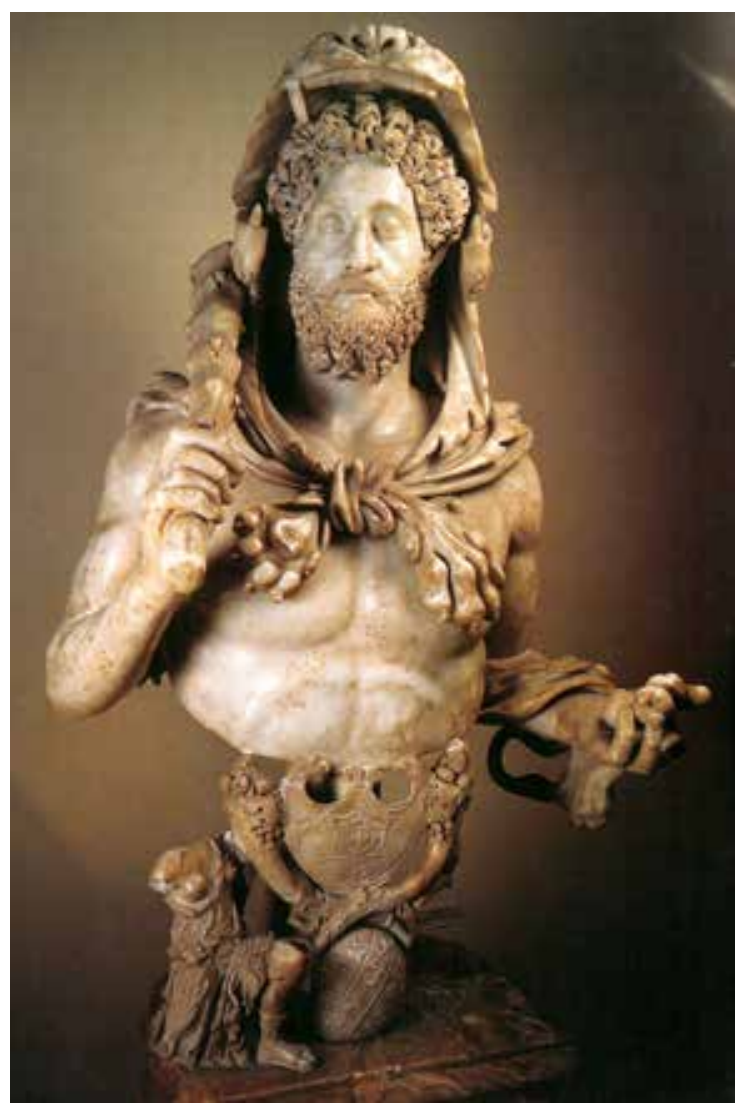

Fig. 3. Marble portrait of Commodus in the guise of Hercules (after Elsner 1998, fig. 132)

signs, but they are not displayed in their chronological sequence. It has been assumed that the signs, representing Taurus, Capricorn, and Scorpio, had a particular importance for the emperor (see Hannah 1986: 337, fts. 3, 4). Robert Hannah proposed a calendric interpretation of these signs, relating them to the constellations visible on the horizon during the month of October, the constellations of the Bull and Scorpion, and that of the Capricorn which was culminating at the time, equidistant between them, just as they are represented on the globe (ibid:: 341). The month of October held a particular significance for Commodus. It was in this month, in 166 , that he was named Ceasar; in October of 172 he was given the title of Germanicus, and in October of 180 he was officially proclaimed Emperor (loc. cit.). Commodus even renamed this month Hercules. He represented himself in the likeness of this mythical hero and with his attributes on other monuments 


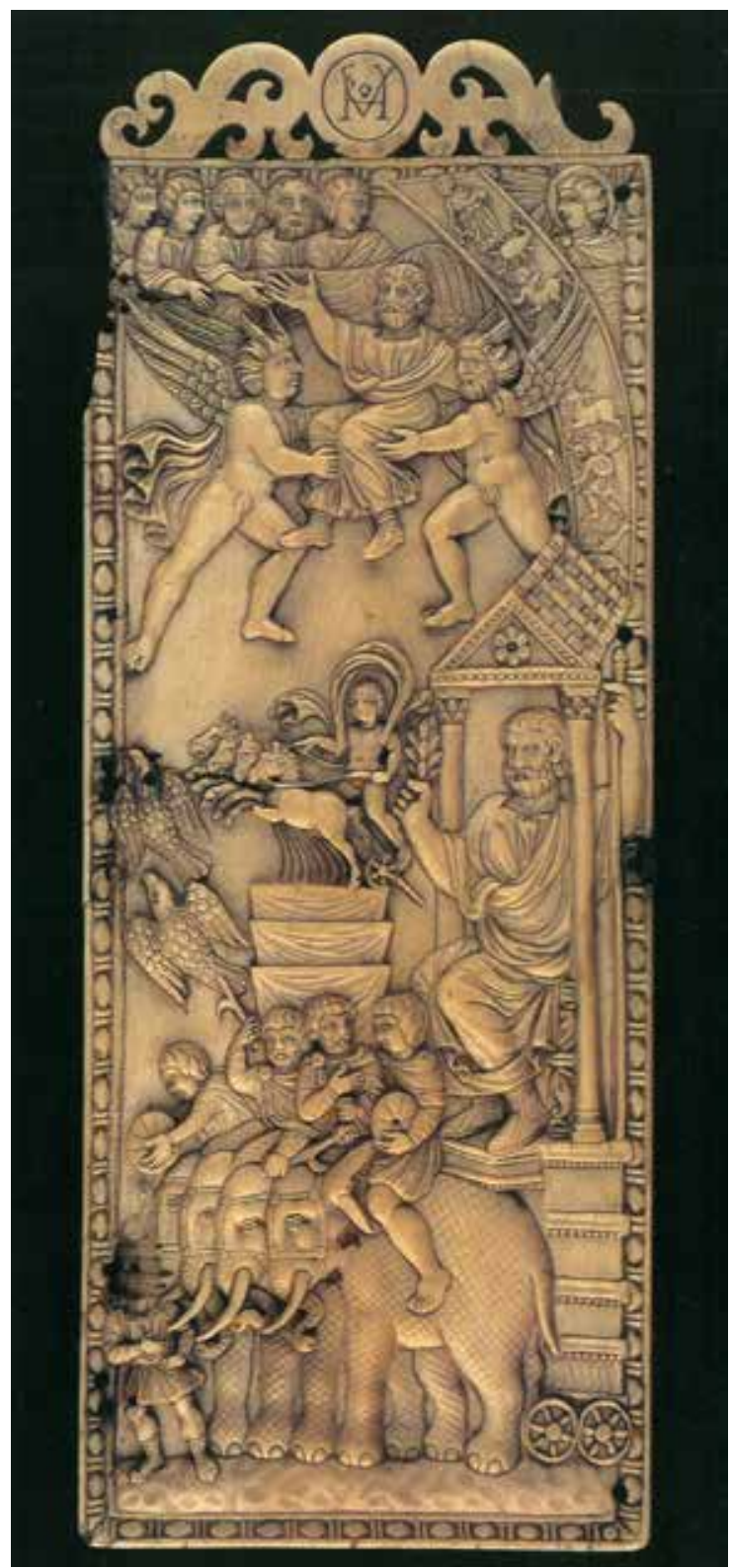

Fig. 4. “Apotheosis Relief”, British Museum, London (after Elsner 1998, fig. 11)

as well, he even used the titles Romanus Hercules or Hercules Commodianus on public inscriptions (loc. cit.; Nasrallah 2010: 174).

Another testament of Commodus' devotion to Hercules is the temple he built and dedicated to this hero in Sabratha, a town in modern day Libya. Italian archaeologists who conducted excavations before the Second World War, uncovered traces of painted decoration. On the fragments of plaster in the calotte of the western apse, a representation of Marcus Aurelius could be reconstructed.
The fresco depicted the scene of his Apotheosis, on which the emperor was shown with a sceptre and a wreath, being carried to heaven on the back of an eagle. The scene was framed by a circle in which the signs of the zodiac were alternating with the figures of human heads, in medallions (Eric Moormann believes these medallions represent imitations of gems and cameos, while Francesca Ghedini sees them as personifications of the twelve months. Moormann 2011: 144, ft. 97; Caputo and Ghedini 1984: 70, 77-9). Images of Hercules himself can be found within the circle of the zodiac, as on the funerary monument of the Secundini family in Igel, near Trier. On the monument, which was made c. $250 \mathrm{AD}$, Hercules is shown carried in a quadriga upward to Minerva extending her hand towards him and welcoming him to the abode of the gods, of which the zodiac encircling the scene is indicative. Another instance of Apotheosis with the zodiac is found on the late antique ivory relief from the British Museum (fig. 4). The so-called "Apotheosis relief" shows the consecration of an unknown emperor or a state dignitary, and is generally dated to the $5^{\text {th }}$ century (for various theories regarding the date and identity of the consecrated figure, see Cameron 2011: 719-728; Kiilerich 2012: 207-8). In the right hand corner of the relief, a segment of a circle is carved showing six of the twelve signs of the zodiac. This relief was probably a part of a diptych, whose other half contained the rest of the zodiac signs. Behind the signs, a nimbed figure can be seen, who is sometimes identified as Sol (Cameron 2011: 719).

Images of Sol are sometimes accompanied by the zodiac. The Sun god is shown within the circle containing the signs on a floor mosaic discovered in the ruins of a Roman villa in Münster-Sarmsheim, dated to mid $3^{\text {rd }}$ century (Bullinger 1976; fig. 5). The central part of the mosaic is on display in the Rheinisches Landesmuseum in Bonn. Zodiac signs also encircle the figures of Helios and Selene on the $4^{\text {th }}$ century floor mosaic from a triclinium of a Roman villa in Sparta (Hachlili 


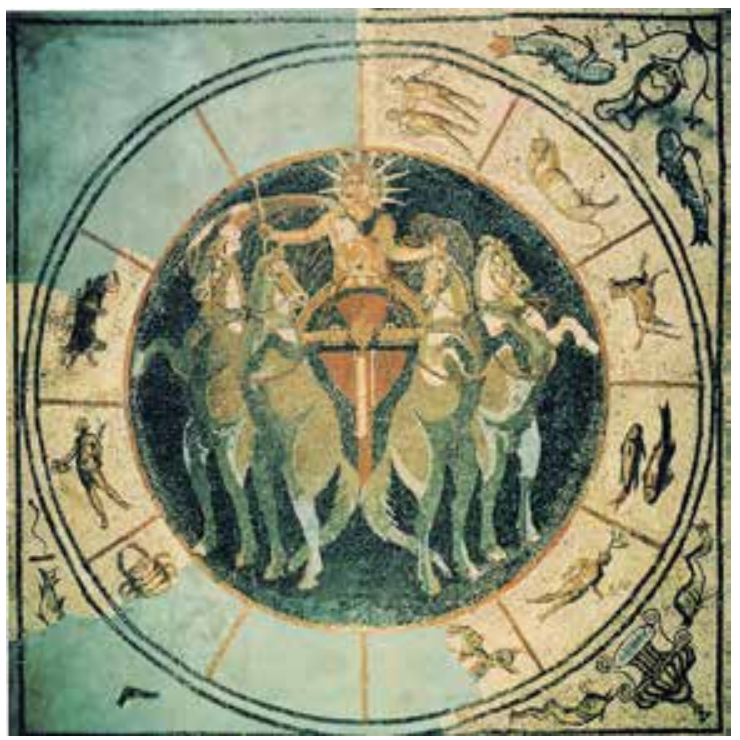

Fig. 5. Mosaic from Münster-Sarmsheim, Rheinsches Landesmuseum, Bonn (after Hachlili 2009, Pl. III- 12a)

2009: 53). They also surround the image of this goddess on a votive relief from Argos, whose architectural setting is unknown, and whose dating is also a matter of dispute (Stephen Patterson insists on a $2^{\text {nd }}$ century date, while William Brashear suggests a later date, as well as Gnostic origins. Patterson1985: 440; Brashear 1990).

Zodiac signs adorned representations of other deities as well. Many statues of the Artemis of Ephesus carry the signs, particularly on the chest area. Since all of the surviving statues belong to the Roman period, it is not certain whether the zodiac motif was a Roman innovation, or if it was present in Hellenistic representations of the goddess (LiDonnici 1992: 407, ft. 74, fig. 6). Other Greco-Roman gods can also appear with the zodiac. Such was the case with Jupiter, as in the aforementioned temple of Bel in Palmyra, but also on some of the later examples, such as the much restored $2^{\text {nd }}$ century relief of Jupiter from Villa Albani (fig. 7). Jupiter together with Juno was placed in the midst of zodiac signs on the Arch of Dativius Victor in Mainz, dating from the middle of the $3^{\text {rd }}$ century. The arch that stands in the park in Mainz is a replica, while the original was built into the city walls in the $4^{\text {th }}$ century and is now housed in the town's Landesmuseum (Cassibry 2008: 421).
Another divinity which was often shown with the zodiac was Aion. Its name was tied to a philosophical concept relating to the idea of eternity, and its image was also considered a personification of the same idea (for different meanings and connotations of the term aion in ancient literature and philosophy, see Keizer 2010; for different mythological associations, see Levi 1944: 275 278). As the oldest securely dated image of Aion with the zodiac, Doro Levi suggests the relief on the base of the column of Antoninus Pius, whose winged figure the author, as do many others, identifies with Aion (Levi 1944, 310-311, ft 126; for an overview of different theories regarding this figure, see Davies 2004, 97, ft. 74). A comparable image of a nude youth can be seen on Hadrian's aureus of 121 , on which a figure holding a globe with a phoenix on top is placed inside the zodiac band and marked with the inscription SAEC(VLVM) AVR(EVM) (Levi 1944: 294; Gury 1984: 7). The zodiac also accompanies Aion on

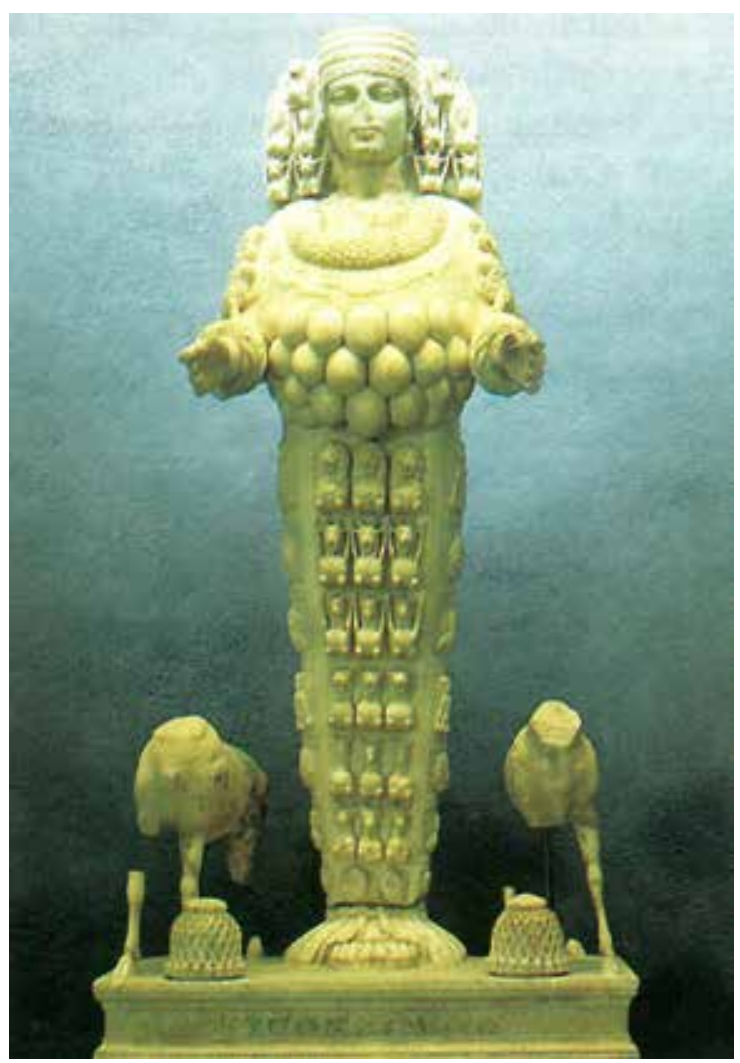

Fig. 6. "Beautiful Artemis”, Efes Müzesi, Selçuk (after Elsner 1998, fig. 134) 


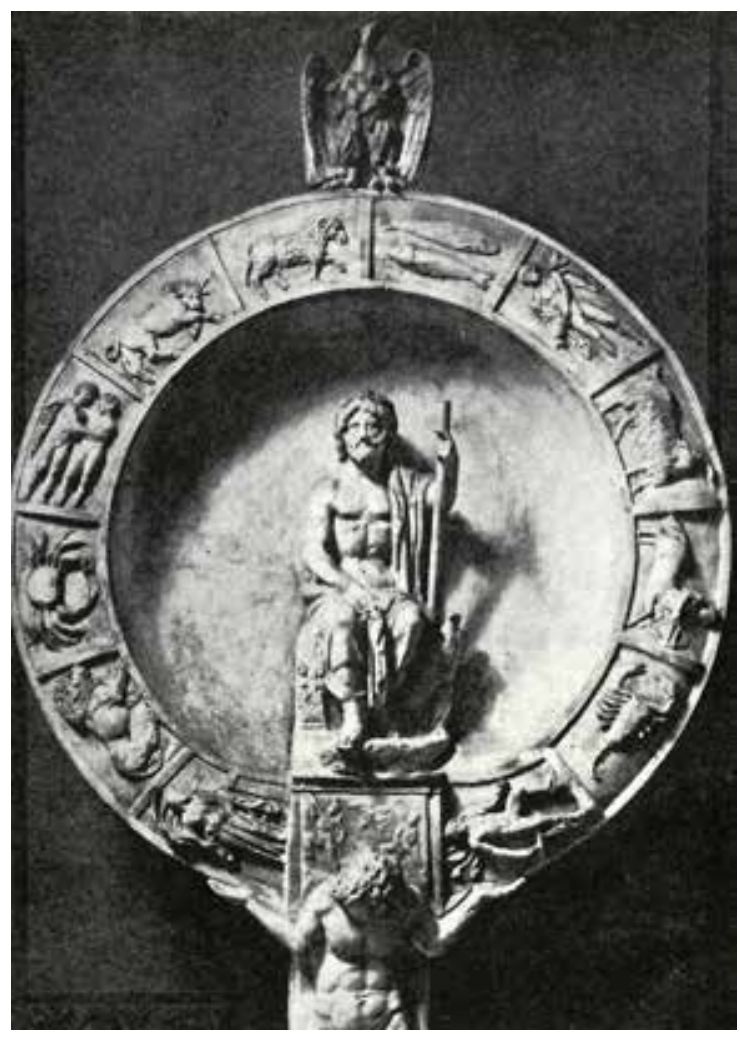

Fig. 7. Relief of Jupiter within the zodiac circle, Villa Albani, Rome (after L'Orange 1953, fig. 67)

the Arch of Galerius in Thessaloniki. On the relief on the eastern side of the southern pier, depicting the Sacrifice of Galerius and Diocletian, behind the draped semi-naked figure identified as Aion (Pond Rothman 1977: 440, 447) an elliptical band with the signs can be discerned (Rees 1993: 196).

Apart from the works of public imperial art, Aion with the zodiac band can be encountered in private settings, represented on a great number of mosaics found in villas throughout the Empire. Among the more renowned examples are those from Sentinummodern Sassoferato in Italy, and the mosaic from the Villa Silin in Leptis Magna in modern Libya. Both mosaics are dated to the $2^{\text {nd }}$ century, as is the mosaic from a triclinium of a house in Trinquetaille near Arles (Parrish 1995: 180). From the $4^{\text {th }}$ century, several examples of mosaics decorated with images of Aion holding the zodiac wheel can be found in the towns of North Africa: the mosaic from Hippo Regius, in Algiers and, in Tunisia, mosaics from Carthagena and from Haïdra (ibid.).
A similar motif can be seen in different media, as can be observed on the silver Parabiago plate (fig. 8). The function of this plate remains unknown, although it was most probably funerary, considering it was found in a grave, covering the mouth of an amphora containing the ashes of the deceased (Alvar 2008: 141. Various dates have been proposed for this plate, ranging from the $2^{\text {nd }}$ to the $4^{\text {th }}$ century, see $i b i d .: 139-140$, ft. 344$)$. The plate is decorated with imagery associated with the cult of Cybele and Attis, and among many other figures, Atlas is shown carrying the zodiac ring, inside which stands a half draped young man holding a sceptre, generally interpreted to be Aion (ibid.: 140-141, ft. 346). Images of Aion are present in the art of other cults as well. Some of them are considered to belong to the art of the cult of Mithra, such as the statue of Aion found in Arles, whose torso is carved with the signs of the zodiac (Vermaseren 1956: 305-6, mon. 879). Mithra himself can be shown with the circle of the zodiac, as on a couple of reliefs thought to depict his birth; on the reliefs from Trier and Housesteads the god is portrayed alternatively as a boy and as a young man within the circle (ibid.: 327, mon. 985; 298, mon. 860). Zodiac signs can also be seen overarching or framing Tauroctony scenes (fig. 9).

Not only gods, divinised heroes and emperors,

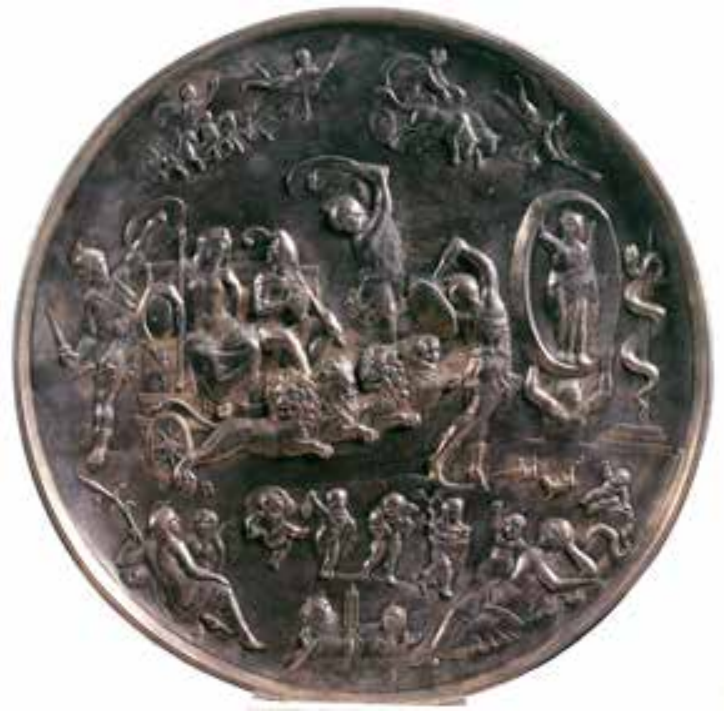

Fig. 8. "The Parabiago Plate", Castello Sforzesco, Milan (after Elsner 1998, fig. 136) 


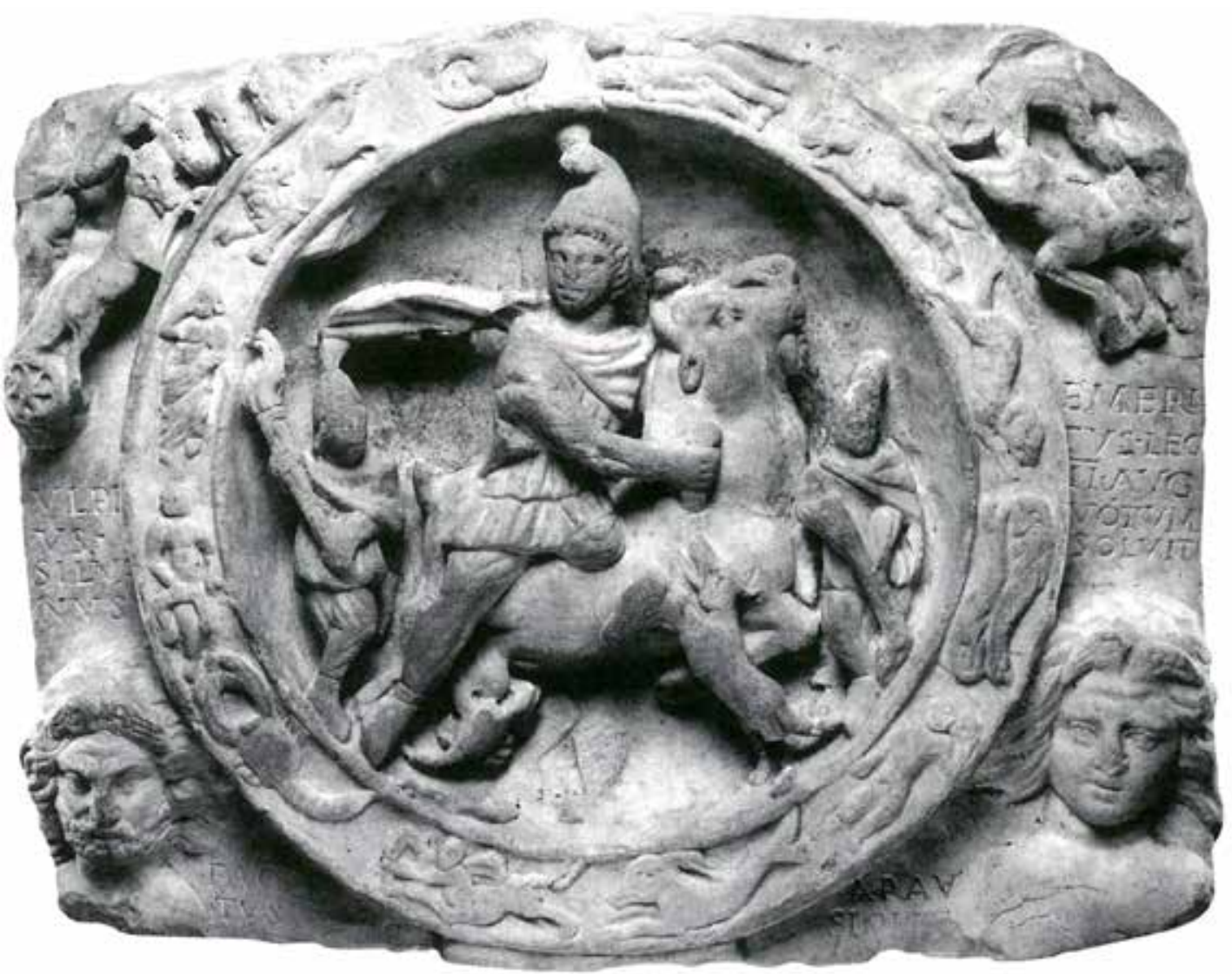

Fig. 9. Marble relief with Tauroctony, London Museum (after Elsner 1998, fig. 143)

but ordinary citizens could also be placed within the circle of the zodiac. On three sarcophagi from the first half of the $4^{\text {th }}$ century, portraits of the deceased are framed by a band with the twelve signs. While the examples preserved in Dumbarton Oaks and Campo Santo in Pisa show images of marital couples, a sarcophagus kept in the National Museum in Sassari displays a portrait of a young woman inside the zodiac (Parodo 2015).

\section{CONCLUSION}

As we can see from the overview of monuments, objects, scenes that included the images of the zodiac, their contexts and purposes were diverse, as were the connotations and the function of the motif itself. The multivalent meaning of the images of the signs was the result of their application in different fields. As the concept of the zodiac was used in astronomy, astrology, and chronometry, the visual renditions of its signs appear on different instruments employed by these disciplines: stellar maps, astrologer's boards, calendars, etc. However, as has been noticed, on some of the devices, particularly those for determining the time of day or the position of the stars, the names of the signs are more often found than their images. Zodiacs were also conspicuous on commemorative monuments and funerary objects. They are frequently found on scenes of Apotheosis. In these cases, the signs of the zodiac designate the destination of the souls of the departed (Parodo 2015: 410). In various cosmological theories, the zone of the fixed stars, to which the constellations of the zodiac belong, represents the outermost sphere of the universe (Wright 2000: 99- 102). This sphere has been identified as the abode of the gods ("caelus hic, in quo duodecim dii habitant, in totidem se figuras convertit, et modo fit aries", 


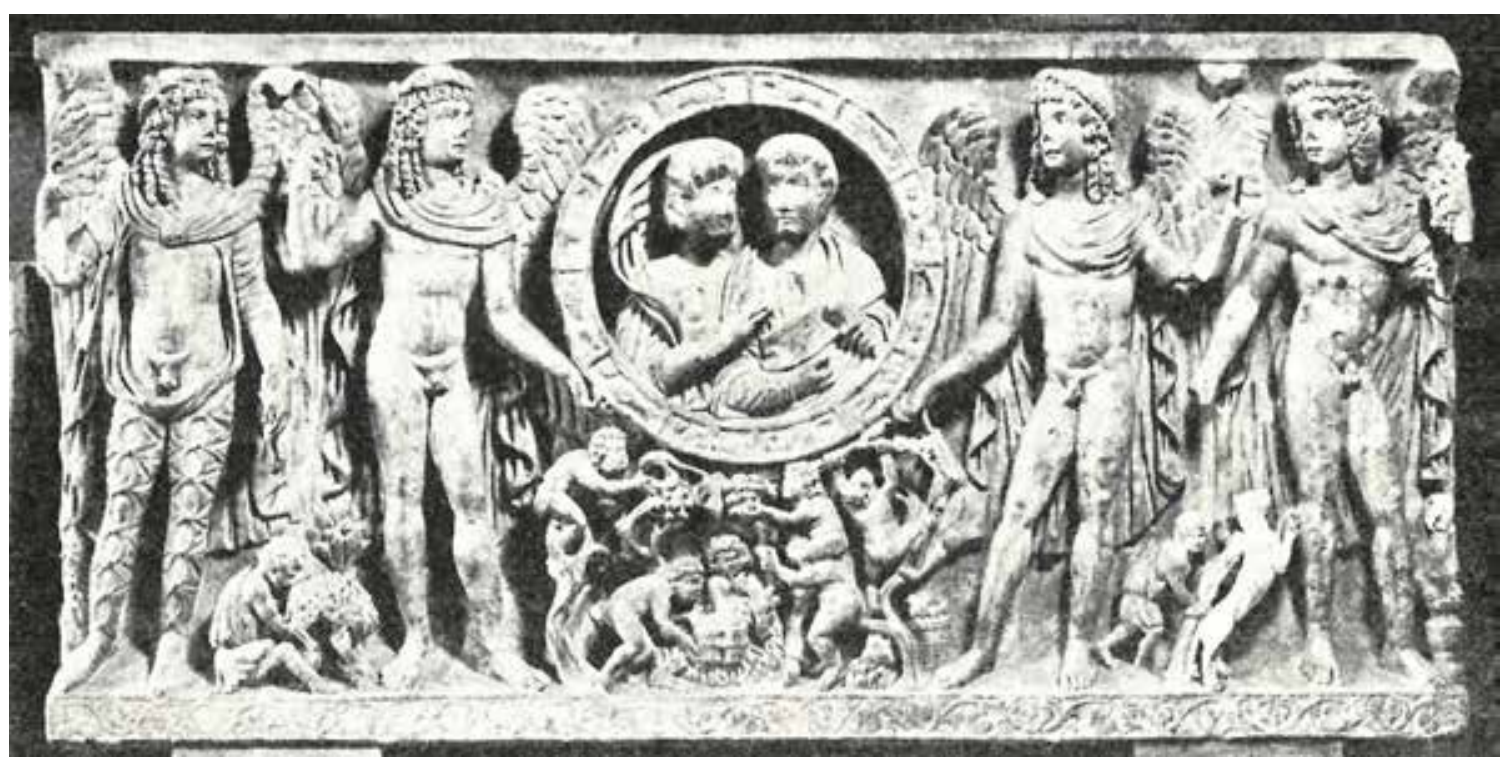

Fig, 10. "Seasons sarcophagus", Dumbarton Oaks Collection, Washington DC (after L'Orange 1953, fig. 62)

Petronius: 39. 5; some scholars believe that this notion was already present in Plato's thought when he connected the Olympian gods with the zodiac in Phaedrus, Cornford 1935: 76). Greek mythology, unlike Babylonian, was not set on a celestial stage. It is with the appearance of Erathostenus' Catasterisms that a mythological explanation for some of the constellations and astral figures is provided. From the Babylonians, the Greeks also adopted the custom of naming planets after gods. Yet, it was the Romans who established the uniform nomenclature of the planets by the end of the Republican age. When they started referring to planets not as stella or sidus Iovis, Saturnis, Martis, etc., but as Iuppiter, Saturnus, or Mars, this change signalled not merely a linguistic shift, but rather a different understanding of the planets and their identification with the gods (Cumont 1935: 34-35). Since, according to astrological notions, planets, by exerting their influence, determined the course of events on Earth, they were considered cosmocratoresrulers of the universe, a term first encountered in the $2^{\text {nd }}$ century Anthologies of Vettius Valens $(\mathrm{Cu}-$ mont and Canet 1919: 318, ft. 3). Since the movements of the planets, including the Sun and the Moon, determined the sequence of time, they were also considered chronocratores (ibid.: 320). Thus, the old Olympian gods, by their associations with the planets and astrological conceptions, came to be represented as universal rulers (Koester 1995: 152). This was made visually manifest on some of the aforementioned examples, such as the Jupiter from Villa Albani, but also on coins, on a compositionally similar reverse of a bronze medallion issued by Alexander Severus in Perinthus, Thrace (Vermeule 1982: 65). The zodiac was also represented on the images of other gods, some of them of oriental origin. While we have mentioned the preponderance of zodiacal imagery in the cult of Mithra, the zodiac also framed images of Sarapis, Isis, and Astarte on a number of coins issued by Antoninus Pius, Julia Maesa and Julia Paula (Geissen 2005: 168, ft. 13; Bijovsky 2010: 99). This iconography can be seen as an effort to promote a certain deity beyond local boundaries of origin and to represent it as a universal ruler (Patterson 1985: 440). It can be viewed against the background of the highly competitive atmosphere of religious pluralism in the Roman Empire, in which a large number of cults wanted to demonstrate their dominance and superiority. The power over elements credited to some of them, as well as the ability of its priests to predict the future, was undoubtedly a potent way to establish this supremacy. 
Even though not all meanings of zodiac images in the ancient world was astrological, in this paper we contend that the influx and development of astrological ideas played a significant part in the popularity of the visual renditions of the signs and the zodiac motif as a whole. While the dating of most Hellenistic examples is contested, an object which is thought to have contained an entire circle of the zodiac is securely dated to the $1^{\text {st }}$ century $\mathrm{BC}$ and is believed to be an astrologer's board. Coincidentally or not, in astrological theory, the zodiac signs are not merely constellations lying on the path of the Sun, or its segments used for determining the positions of the stars and for designating time, they determined the fates of individuals, states and entire nations. It was mostly with predictions concerning the future of the state and the sovereign that the Babylonian proto-astrologers dealt with. Their number could have never been great, for their expertise required literacy and years of education. Thus, their services must have been costly and only available to the most affluent, perhaps solely to the head of state. Democratisation of astral divination ensued with the invention of the zodiac, which facilitated the production of astrological calculations and allowed a greater number of people to obtain predictions from astrologers. They came to be acquainted with visual renditions of the signs which already in the $1^{\text {st }}$ century $\mathrm{AD}$ started to be represented in the decoration of private spaces and objects. From the $1^{\text {st }}$ century dates the earliest astrological work preserved in its entirety- Astronomica by Marcus Manilius. This work was dedicated to an emperor, Augustus or Tiberius, perhaps even commissioned by one of them (Cramer 1954: 95-6). From the time of Augustus, individual zodiac signs were depicted on coins. However, the whole circle of the twelve signs is encountered for the first time on coins issued by Antoninus Pius. In the $8^{\text {th }}$ year of his rule (144/145 AD), a series of bronze coins was minted in Alexandria, showing the busts of Sarapis, or Sarapis and Isis together, as well as Helios and Selene framed by the zodiac signs. The same mint, in the same year, issued a series of drachmes with twelve types of reverses each showing one of the signs of the zodiac together with one of the planets (Sayles 1998: 98). Whatever the occasion for the issuing of these coins was (see Geissen 2005: $168, \mathrm{ft} .13$ ), it is during the reign of Antoninus that Ptolemy wrote his Tetrabiblos and Vettius Valens his Anthologies. From the $2^{\text {nd }}$ century onward, we witness an increase in zodiacal representations, particularly on works of public imperial art. While there are certainly other factors contributing to the popularisation of this motif, such as its presence in cosmological and eschatological theories of the Classical world, many of them were imbued with astrological notions. As Porphiry tells us, followers of the Mithraic cult believed that the soul on its descent to Earth and ascent to Heaven, passed through the gates that are situated on the zodiac (Porphiry: 11), a belief also present among other groups and thinkers (DeKonick 2013: 55-65).

After the fall of the western part of the Roman Empire, the zodiac would not be seen on artefacts produced in its territories for almost five centuries. Like the art of casting horoscopes, the images of the signs were also forgotten. When they reemerged, the signs of the zodiac were seen on the pages containing astrological predictions in a $9^{\text {th }}$ century manuscript from Fulda (Basel, Universitätsbibliothek F III 15a. Obrist 2001: 3-4). Also, a surge of zodiacal imagery can be witnessed on the facades and in the interiors of Romanesque churches, as Western Europe was being reintroduced to astrological texts via translations from the Arabic manuscripts. Likewise, a revived interest in astrology during the Renaissance, following the influx of Greek books brought by Byzantine refugees, coincided with an increase of astrological and zodiac motifs in the visual arts. Throughout the entire pre-modern era, a similar tendency can, thus, be perceived; that the appearance and preponderance of visual representations of the twelve signs is concomitant with major developments in the history of astrology. From the historical overview and the material 
presented in this paper, it can be ascertained that those tendencies were already present in Antiquity.

\section{$* * *$}

Arheologija i prirodne nauke (Archaeology and Science) is an Open Access Journal. All articles can be downloaded free of charge and used in accordance with the licence Creative Commons - Attribution-NonCommercial-NoDerivs 3.0 Serbia (https://creativecommons.org/licenses/bync-nd/3.0/rs/.

Časopis Arheologija i prirodne nauke je dostupan u režimu otvorenog pristupa. Članci objavljeni u časopisu mogu se besplatno preuzeti sa sajta i koristiti u skladu sa licencom Creative Commons - Autorstvo-Nekomercijalno-Bez prerada 3.0 Srbija (https://creativecommons.org/licenses/bync-nd/3.0/rs/.

\section{BIBLIOGRAPHY}

\section{Aratus}

Phaenomena, trans. G. R. Mair, Loeb Classical Library Vol. 129, London: William Heinemann, 1921.

\section{Alvar, J. 2008.}

Romanising Oriental Gods: Myth, Salvation, and Ethics in the Cults of Cybele, Isis, and Mithras, trans. R. Gordon, Religions in the Graeco-Roman World, Vol. 165, Leiden: Brill

\section{Baratta, G. 2014.}

Ripetizioni e varianti epigrafiche ed iconografiche nelle serie ceramiche di Gaius Valerius Verdullus: il così detto "vaso dello zodiaco». L'iscrizione e il suo doppio. Atti del Convegno Borghesi 2013. A. Donati (ed). Faenza: Fratelli Lega: 109-156.

\section{Barton, T. 1995.}

Augustus and Capricorn: Astrological Polyvalency and Imperial Rhetoric, The Journal of Roman Studies 85: 33-51.
Beck, R. 2007.

A Brief History of Ancient Astrology, Brief Histories of the Ancient World, Oxford: Blackwell Publishing.

Bijovsky, G. 2010.

The Coins from Iqrit, 'Atiqot 62: 97-106.

\section{Bodnár, S. 2007.}

Two Fragments of a Renaissance Bronze Zodiac Frieze, Metropolitan Museum Journal 42: 95-105.

\section{Boyancé, P. 1942.}

Le disque de Brindisi et l'apothéose de Sémélé, Revue des Études Anciennes 44/3-4: 191-216.

Brashear, W. 1990.

A Further Note on an Argive Votive Relief of Selene, Harvard Theological Review 83/3: 333-339.

\section{Bullinger, H. 1976.}

Münster-Sarmsheim, Rhineland Palatinate, Germa$n y$, in: The Princeton encyclopedia of classical sites, R. Stillwell, W. L. M. MacDonald and M. Holland (eds.), Princeton NJ: Princeton University Press.

\section{Cameron, A. 2011.}

The Last Pagans of Rome, Oxford: Oxford University Press.

\section{Campion, N. 2008.}

A History of Western Astrology, Volume I: The Ancient World, London: Bloomsbury Academic.

\section{Caputo, G. and Ghedini, F. 1984.}

Il Tempio d'Ercole di Sabratha, Monografie di archeologia libica 19, Roma: "L'Erma" di Bretschneider.

\section{Cassibry, K. 2008.}

Provincial Patrons and Commemorative Rivalries: Rethinking the Roman Arch Monument, Mouseion: Journal of the Classical Association of Canada 8/3: 417-450. 


\section{Cassius Dio}

Roman History, trans. E. Cary, Loeb Classical Library Vol. 177, London: William Heinemann, 1914-1927.

\section{Cicero}

On the Commonwealth and on the Laws, J. E. G. Zetzel (ed.), Cambridge Texts in the History of Political Thought, Cambridge: Cambridge University Press 1999.

\section{Clagett, M. 1995.}

Ancient Egyptian Science: a Sourcebook, Volume Two, Calendars, Clocks, and Astronomy, Memoirs of the American Philosophical Society Vol. 214, Philadelphia: American Philosophical Society.

\section{Clement of Alexandria}

Stromata, trans. W. Wilson, Ante-Nicene Fathers, Vol. 2, Buffalo NY: Christian Literature Publishing Co., 1885.

\section{Cornford, F. M. 1935.}

Plato's Cosmology, The Timaeus of Plato, Cambridge: Routledge, reprint 1997, Indinanapolis IN: Hackett Publishing Company, Inc.

\section{Cramer, F. H. 1954.}

Astrology in Roman Law and Politics, Memoirs of the American Philosophical Society Vol. 37, Philadelphia: The American Philosophical Society.

Cumont, F. and Canet, L. 1919.

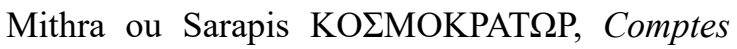
rendus des séances de l'Académie des Inscriptions et Belles-Lettres 63/4 : 313-328.

\section{Cumont, F. 1935.}

Les noms des planètes et l'astrolatrie chez les Grecs, L'antiquité classique 4: 5- 43.

Davies, P. J. E. 2004.

Death and the Emperor, Roman Imperial Funerary Monuments from Augustus to Marcus Aure- lius, Austin TX - Cambridge: University of Texas

Press; Cambridge University Press.

DeConick, A. 2013.

The Road for the Souls Is through the Planets: The Mysteries of the Ophians Mapped, in: Practicing Gnosis: Ritual, Magic, Theurgy and Liturgy in Nag Hammadi, Manichaean and Other Ancient Literature, Essays in Honor of Birger A. Pearson, A. DeConick, G. Shaw, J. D. Turner (eds.), Nag Hammadi and Manichaean Studies Vol. 85, Leiden - Boston: Brill, 37-75.

\section{Dieleman, J. 2003.}

Stars and the Egyptian Priesthood in the Graeco-Roman Period, in: Prayer, magic, and the stars in the ancient and late antique world, S. Noegel, J. Walker, B. Wheeler (eds.), Magic in History Series, University Park PA: The Pennsylvania State University Press, 137-155.

Duke, D. W. 2006.

Analysis of the Farnese Globe, Journal for the History of Astronomy 37: 87-100.

Elsner, J. 1998.

Imperial Rome and Christian Triumph, The Art of the Roman Empire AD 100-450, Oxford History of Art, Oxford: Oxford University Press.

Evans, J. 2004.

The Astrologer's Apparatus: A Picture of Professional Practice in Greco-Roman Egypt, Journal for the History of Astronomy xxxv: 1-44.

Forenbaher, S. and Jones, A. 2011.

The Nakovana Zodiac: Fragments of an Astrologer's Board from and Illyrian-Hellenistic Cave Sanctuary, Journal for the History of Astronomy xlii: 425-438.

Geissen, A. 2005.

The Nome Coins of Roman Egypt, in: Coinage and Identity in the Roman Provinces, C. How- 
gego, V.Heuchert, and A. Burnett (eds.), Oxford: Oxford University Press, 167- 170.

\section{Gury, F. 1984.}

Aiôn juvénile et l'anneau zodiacal: l'apparition du motif, Mélanges de l'École française de Rome 96/1: 7-28.

\section{Gury, F. 1986}

La forge du destin [À propos d'une série de peintures pompéiennes du IVe style], Mélanges de l'École française de Rome 98/2: 427-489.

\section{Hachlili, R. 2009.}

Ancient Mosaic Pavements: Themes, Issues, and Trends, Selected Studies, Leiden: Brill.

\section{Hannah, R. 1986.}

The Emperor's Stars: The Conservatori Portrait of Commodus, American Journal of Archaeology 90/ 3: 337-342.

\section{Hannah, R. 2009.}

Time in Antiquity, Sciences in Antiquity, London New York: Routledge.

\section{Hardie, P. R. 1985.}

Imago Mundi: Cosmological and Ideological Aspects of the Shield of Achilles, The Journal of Hellenic Studies 105: 11-31.

\section{Hunger, H. and Pingree, D. 1999.}

Astral Sciences in Mesopotamia, Leiden: Brill.

\section{Iwaniszewski, S. 2003.}

Archaeoastronomical analysis of Assyrian and Babylonian monuments: methodological issues, Journal for the History of Astronomy 34/1, 114: 79 - 93.

\section{Jacobus, H. R. 2015.}

Zodiac Calendars in the Dead Sea Scrolls and Their Reception, Ancient Astronomy and Astrology in Early Judaism, IJS Studies in Judaica, Leiden - Boston: Brill.

\section{Juvenal}

The Sixteen Satires, trans. S. H. Jeyes, Oxford: James Thornton, 1885.

\section{Keizer, H. M. 2010.}

Life Time Entirety, A Study of AISN in Greek Literature and Philosophy, the Septaguint and Philo, PhD Thesis, Universiteit van Amsterdam.

\section{Keler, H. 1970.}

Rimsko Carstvo, prev. M. Garašanin, Umetnost u svetu, istorijske, društvene i religiozne osnove, Novi Sad: Izdavačko preduzeće »Bratstvo Jedinstvo«.

\section{Kerenyi, C. 1976.}

Dionysos, Archetypal Image of Indestructible Life, trans. R. Manheim, Bollingen Series LXV, Princeton NJ: Princeton University Press.

\section{Kiilerich, B. 2012.}

Symmachus, Boethius and the Consecratio Ivory Diptych, Antiquité Tardive 20: 205-215.

\section{Koester, H. 1995.}

Introduction to the New Testament, Volume I: History, Culture, and Religion of the Hellenistic Age, second edition, New York-Berlin: Walter de Gruyter \& Co.

\section{Koch-Westenholz, U. 1995.}

Mesopotamian Astrology: An Introdustion to Babylonian and Assyrian Celestial Divination, CNI Publications 19, Copenhagen: Museum Tusculanum Press.

\section{Lehoux, D. 2007.}

Astronomy, Weather, and Calendars in the Ancient World: Parapegmata and Related Texts in Classical and Near-Eastern Societies, Cambridge: Cambridge University Press.

\section{Levi, D. 1944.}

Aion, Hesperia: The Journal of the American School of Classical Studies at Athens 13/ 4: 269-314 
LiDonnici, L. R. 1992.

The Images of Artemis Ephesia and Greco-Roman Worship: A Reconsideration, The Harvard Theological Review 85/4: 389-415

Long, C. R. 1987.

The Twelve Gods of Greece and Rome, Études préliminaires aux religions orientales dans l'Empire romain, Vol. 107. Leiden: Brill.

\section{Long, C. R. 1989.}

The Gods of the Months in Ancient Art, American Journal of Archaeology 93/4: 589-595.

\section{L'Orange, H. P. 1953.}

Studies on the Iconography of Cosmic Kingship in the Ancient World, Oslo: Instituttet for Sammenlignende Kulturforskning.

Mavroudi, M. 2006.

Occult Sciences and Society in Byantium: Considerations for Future Research, in: The Occult Sciences in Byzantium, P. Magdalino and M. Mavroudi (eds.), Geneva: La Pomme D’Or.

Moormann, E. 2011.

Divine Interiors, Mural Paintings in Greek and Roman Sanctuaries, Amsterdam Archaeological Studies 16, Amsterdam: Amsterdam University Press.

Nasrallah, L. 2010.

Christian Responses to Roman Art and Architecture: The Second Century Church Amid the Spaces of Empire, Cambridge: Cambridge University Press.

\section{Obrist, B. 2001.}

La représentation carolingienne du zodiaque. A propos du manuscrit de Bâle, Universitätsbibliothek, F III 15a, Cahiers de civilisation médiévale 44/173: 3-33.

Palagia, O. 2008.

The date and iconography of the calendar frieze on the little metropolis, Athens, Jahrbuch des Deutschen Archäologischen Instituts 123: 215-237.

Parodo, C. 2015.

Il cammino degli immortali. Il sarcofago con ritratto di defunta entro cerchio astrologico del $\mathrm{Mu}-$ seo Nazionale "G.A. Sanna" di Sassari e lo zodiaco come porta di ingresso nell'eternità, Quaderni della Soprintendenza Archeologia della Sardegna 26: 407-431.

\section{Parrish, D. 1995.}

The Mosaic of Aion and the seasons from Haïdra (Tunisia): an interpretation of its meaning and importance, Antiquité Tardive 3: 167-190.

Patterson, S. J. 1985.

A Note on an Argive Votive Relief of Selene, Harvard Theological Review 78, 3/4: 439-445

\section{Pines, S. 1964.}

The Semantic Distinction between the Terms Astronomy and Astrology according to al-Biruni, Isis 55/ 3: 343-349.

\section{Petronius}

Satyricon, trans. M. Haseltine, London: William Heinemann, 1913.

\section{Plunket, E. 1903}

Calendars and Constellations of the Ancient World, reprint 2005. New York: Cosimo Classics.

Pollini, J. 2012.

From Republic to Empire: Rhetoric, Religion, and Power in the Visual Culture of Ancient Rome, Norman OK: University of Oklahoma Press.

\section{Pond Rothman, M. S. 1977.}

The Thematic Organization of the Panel Reliefs on the Arch of Galerius, American Journal of Archaeology 81/4: 427-454.

\section{Porphyry}

On the Cave of the Nymphs in the Thirteenth Book 
of the Odyssey, trans. T. Taylor, London: John M. Watkins, 1917.

Powell, R. 2007.

History of the Zodiac, San Rafael CA: Sophia Academic Press.

\section{Rees, R. 1993.}

Images and Image: A Re-Examination of Tetrarchic Iconography, Greece \& Rome 40/2: 181-200.

Sayles, W. G. 1998.

Ancient Coin Collecting IV: Roman Provincial Coins, Iola WI: Krause Publications.

\section{Schaefer, B. E. 2005.}

The epoch of the constellations on the Farnese atlas and their origin in Hipparchus' lost catalogue, Journal for the History of Astronomy xxxvi: 167-196.

Simon, E. 1983.

Festivals of Attica: an Archeological Commentary, Madison WI: The University of Wisconsin Press.

\section{The Scriptores Historia Augusta}

trans. D. Magie, Loeb Classical Library 139, Cambridge MA: Harvard University Press, 1924.

Tester, J. 1987.

A History of Western Astrology, Woodbridge: The Boydell Press.

\section{Torelli, M. 1992}

Typology \& Structure of Roman Historical Reliefs, Thomas Spencer Jerome Lectures 14, Ann Arbor MI: The University of Michigan Press.

\section{Vermaseren, M. J. 1956.}

Corpus Inscriptionum et Monumentorum Religionis Mithriacae, Hague: Martinus Nijhoff.

\section{Vermeule, C. 1982.}

Alexander the Great, the Emperor Severus Alexander and the Aboukir medallions, Schweizeri- sche numismatische Rundschau = Revue suisse de numismatique $=$ Rivista svizzera di numismatica 61: 61-72.

van der Waerden, B. L. 1952-53.

History of the Zodiac, Archiv für Orientforschung 16: 216-230.

Webster, J. C. 1938.

Labours of the Months in Antique and Medieval Art to the End of the Twelfth Century, Evanston Chicago: Northwestern University.

Wright, J. E. 2000.

The Early History of Heaven, Oxford: Oxford University Press.

\section{REZIME}

ETAPE I TENDENCIJE U ISTORIJI ASTROLOGIJE I NJIHOV UTICAJ NA POPULARIZACIJU MOTIVA ZODIJAKA U VIZULENIM KULTURAMA STAROG VEKA

\section{KLJUČNE REČI: ASTROLOGIJA, ASTRALNO PREDVIĐANJE, ZODIJAK, VIZUELNA KULTU- RA.}

Zodijak je nastao na području Vavilonije, kao koordinatni sistem za određivanje položaja nebeskih tela. Primarna namena mu je bila astronomska, iako je upotrebljavan u hronometriji, poljoprivredi, medicini, kao i u različitim divinatornim tehnikama. Uvođenje zodijaka od dvanaest jednakih delova u petom veku p.n.e. dovelo je do nastanka horoskopske astrologije, koja će postati dominantni vid predviđanja budućnosti na području Ahemenidskog carstva, odakle će se ubrzo proširiti i u druge oblasti.

Premda za neke od predstava možemo pretpostaviti da prikazuju pojedine znake zodijaka ili njihova korespondirajuća sazvežđa, u asirsko-vavilonskoj vizuelnoj kulturi ne nalazimo nijedan sačuvan prikaz čitavog zodijaka. Najstariji spo- 
menici na kojima se može videti ovaj motiv se mahom datuju u period helenizma, ali je većina starovekovnih primera nastala na području Rimskog carstva. Već u prvim decenijama vladavine Julievsko-klaudijevske dinastije, zodijak se može uočiti u dekoraciji privatnih prostora i predmeta za ličnu upotrebu, ali i u hramovima i na javnim spomenicima. Od perioda vladavine Hadrijana i njegovih naslednika, zodijak se sve učestalije sreće na carskim spomenicima i novcu. Ovaj motiv će postati prisutan i u umetostima različitih kultova širom carstva, kako onih istočnjačkog porekla, tako i onih posvećenim božanstvima grčko-rimskog panteona. Tokom čitavog carskog perioda, zodijak će se pojavljivati i u funerarnom kontekstu, budući da je često prikazivan zajedno sa preminulim carevima, divinizovanim herojima, ali i običnim građanima. Sve do pada njegovog zapadnog dela, zodijak je predstavljao popularan motiv u vizuelnoj kulturi Rimskog carstva.

U ovom radu težimo da pokažemo kako je na popularnost ovog motiva u velikoj meri uticao razvoj astrološke teorije, njeno širenje, dostupnost, kao i preovlađujući stavovi prema njenom praktikovanju. Iako su datovanja najstarijih predstava zodijaka predmet sporenja u nauci, nijedna od njih nije nastala pre doba helenizma, tokom kog su ostvareni i najznačajniji pomaci u oblastima astronomije i astrologije. Od uspostavljanja carske vlasti u Rimu, astrologija je stekla veliki broj pristalica među širim stanovništvom, ali i među carevima koji su je upotrebljavali u propagandne svrhe. Poznato nam je da je Avgust, kao i njegov nasledik, Tiberije, koristio usluge astrologa. Tokom vladavine jednog od njih nastalo je i najstarije astrološko delo sačuvano u celosti- Astronomika Marka Manilija. Tiberije je i sâm vršio astrološke proračune, kao i Hadrijan, kako nam prenose pojedini izvori. Tokom Hadrijanove vladavine, zodijak se može uočiti na spomenicima poput „Oltara iz Gabija”, kao i na primerima novca ovog cara čiji su reversi nosili natpisi SAEC(VLUM) AVR(EVM). Dok su na nekim primercima tog novca znaci zodijaka samo naznačeni, svih dva- naest znakova mogu se videti na novcu iskovanom u kovnici u Aleksandriji za vreme vladavine Antonina Pija. Tokom njegove vladavine nastala su i najznačajnija dela ,naučne” astrologije, čije su metode i principi bili usklađeni sa prirodnom filozofijom tog vremena. U pitanju su Ptolomejev Tetrabiblos i Antologije Vetija Valensa. Veliki broj horoskopa sačuvanih iz ovog vremena takođe svedoči o stepenu popularnosti koji je astrologija uživala među rimskim stanovništvom. Astrologija je bila praktikovana i u okviru pojedinih kultova, dok su mnogi od njih zastupali verovanja prožeta astrološkim idejama, kako saznajemo iz pojedinih izvora i kako zaključuju kasniji istraživači. Iako primarno značenje većine kompozicija koje uključuju predstave zodijaka nije astrološko, rasprostranjenost astrologije i poznavanje njenih načela uticalo je na zastupljenost motiva u različitim sferama vizuelne kulture Rimskog carstva. 